


\title{
Intellectual property law in the field of sports: specifics of manifestations and features of legal regulation
}

\author{
DOI: https://doi.org/10.46398/cuestpol.3969.33
}

\author{
Evgen Kharytonov * \\ Olena Kharytonova ** \\ Maxym Tkalych *** \\ Inna Bolokan **** \\ Hanna Samilo $* * * * *$ \\ Yuliia Tolmachevska ******
}

\begin{abstract}
The article aims to explore the relationships that arise with respect to intellectual property rights in sports. The objectives of the article are to establish points of contact between intellectual property law and sports, as well as a detailed analysis of relevant public relations in terms of intellectual property law and sports
\end{abstract} law. To achieve the objectives of the article, the authors used a number of scientific methods, among which the main methods are analysis, synthesis and comparative-legal method. The authors of the study concluded that modern sport is developing in close intertwining with intellectual property rights, because only in this way can a sports spectacle be conveyed to a wide range of spectators and consumers in a broad sense. In addition, the range of points of contact between intellectual property and sports law is constantly growing and such can now be called not only patents and trademarks in sports, but also copyright, "image" rights, know-how in sports and the like.

* Doctor of Legal Science. Professor of Civil Law Department and Head of same Department at National University “Odesa Law Academy”, Odesa, Ukraine. Corresponding Member of National Academy of Law Sciences of Ukraine. Honored Science and Technology Worker of Ukraine. ORCID ID: https:// orcid.org/oooo-0001-5521-0839. Email: zharuton@gmail.com

** Doctor of Legal Science, Professor of Intellectual Property and Corporate Law Department and Head of same Department at National University "Odesa Law Academy". Corresponding Member of National Academy of Law Sciences of Ukraine. Honored Science and Technology Worker of Ukraine. ORCID ID: https://orcid.org/oooo-0002-9681-9605. Email: lh2512@gmail.com

*** Ph. D., Associate Professor of Civil Law Department of Zaporizhzhia National University, Zaporizhzhia, Ukraine. ORCID ID: https://orcid.org/oooo-0oo3-4224-7231. Email: maxx.tkalich@gmail.com

**** Doctor of Legal Science, Associate Professor of Civil Law Department of Zaporizhzhia National University (Zaporizhzhia, Ukraine). ORCID ID: https://orcid.org/oooo-00o3-1868-7552. Email: innabolokani@gmail.com

***** Ph. D., Associate Professor of the Department of Constitutional, administrative, and labor law at Zaporizhzhia Polytechnic National University, Zaporizhzhia, Ukraine. ORCID ID: https://orcid. org/oooo-0oo1-9493-8013. Email: Samiloann2gmail.com

****** Ph.D. candidate of Civil Law Department at National University "Odesa Law Academy", Odesa, Ukraine. ORCID ID: https://orcid.org/oooo-0002-7964-8875. Email: Yuliiatolmachevska7@gmail. com 
Keywords: WIPO (World Intellectual Property Organization), Intellectual Property, Trademark, Design, Image Rights.

\title{
Derecho de propiedad intelectual en el campo de los deportes: detalles de las manifestaciones y características de la regulación legal
}

\section{Resumen}

Este artículo tiene como objetivo explorar las relaciones que surgen con respecto a los derechos de propiedad intelectual en el ámbito del deporte. En particular, los objetivos del artículo son establecer puntos de contacto entre el derecho de propiedad intelectual y el deporte, así como propiciar un análisis detallado de las relaciones públicas relevantes en términos de derecho de propiedad intelectual y derecho deportivo. Para lograr los objetivos del artículo, los autores utilizaron una serie de métodos científicos, entre los cuales los métodos principales son el análisis, la síntesis y el método de derecho comparado. Los atores concluyeron que el deporte moderno se está desarrollando en estrecha relación con los derechos de propiedad intelectual, porque solo de esta manera se puede transmitir un espectáculo deportivo a una amplia gama de espectadores y consumidores en un sentido amplio. Además, la gama de puntos de contacto entre la propiedad intelectual y el derecho deportivo está en constante crecimiento y ahora pueden llamarse no solo patentes y marcas comerciales en los deportes, sino también, derechos de autor, derechos de «imagen», conocimientos técnicos en los deportes y similares.

Palabras clave: OMPI (Organización Mundial de la Propiedad Intelectual); propiedad intelectual; marca registrada; diseño; derechos de imagen.

\section{Introduction}

\begin{abstract}
"Intellectual property rights underlie and empower the financial model of all sporting events worldwide. IP rights lie at the heart of the global sports ecosystem and all the commercial relationships that make sports happen and that allow us to tune in to sporting action whenever, wherever, and however we want" (WIPO, 2020: s/p.
\end{abstract}

These words were said by WIPO Director General Francis Gurry for World Intellectual Property Day 2019 - Reach for Gold: IP and Sports. This quote surprisingly successfully reveals the role of intellectual property 
Evgen Kharytonov, Olena Kharytonova, Maxym Tkalych, Inna Bolokan, Hanna Samilo y Yuliia Tolmachevska

rights in the development of modern sports, the main feature of which is commercialization. Accordingly, modern sport is a spectacle, and it is the institution of intellectual property law that acts as a kind of link between a sports spectacle and its consumers.

In the context of the above said, the issues of legal regulation of relations related to the protection of intellectual property rights in sports are of great scientific and practical interest. In fact, the study of the peculiarities of the legal regulation of these relations is the main purpose of this article.

As social relations in the field of sports became more complicated, there was an increasing need for their proper legal regulation (Kharytonov et al., 2021). Ukrainian legislation provides for the state to care for the development of physical culture and sports (Bolokan et al., 2021). Modern sport needs private legal mechanisms of regulation, because they provide the best way to protect the rights of individuals and legal entities - participants in relations in the field of sports (Tkalych et al., 2020). At the same time, both national and transnational legal systems and the "sports law and order" are gradually improving the legal and quasi-legal mechanisms of the regulation (Kolomoiets et al., 2021).

In addition, considering the concept of this article, the authors aimed to propose an adequate model of legal and quasi-legal regulation of relations arising in relation to intellectual property in sports. After all, relations in the field of sports have their own specifics, respectively, such relations cannot always be qualitatively regulated by general legal norms. In this case, it is necessary to adopt special regulations that would contain legal norms adapted to the specifics of the relevant area of legal regulation, in this case - the field of sports.

\section{Methodology of the study}

To achieve the objectives of the article, the authors used several scientific methods, among which the main methods are analysis, synthesis, and comparative-legal method.

Firstly, it should be noted that, the method of analysis was used to study the current national and foreign legislation in the field of intellectual property and sports.

Additionally, it is worth mentioned that the method of synthesis, in turn, allowed us to identify the main trends in the development of social relations, which are formed at the junction of intellectual property rights and sports. 
Finally, using the comparative-legal method, respectively, the norms of the legislation in the field of sports and intellectual property were analyzed and possible ways of its improvement were suggested.

\section{Analysis of recent research}

About research on intellectual property rights in the field of sports, it should be noted that traditionally the greatest attention is paid to the problems of the sports brand. Therefore, even a sports brand is not enough researched topic in jurisprudence. The question of defining the concept brand, its components, as well as the features of providing legal protection to structural components as part of a single object of intellectual property is considered in the works of Androschuk (2008; 2011a; 2011b); Kodynets (2006); Kulinich (2016); Rassomakhina (2008); Romanadze (2008); Sadovnyk (2015), and Pihurets (2005).

Among foreign authors, the subject of problems of protection of intellectual property rights in sports was dealt with Anderson (2017) and Sharma (2017); as well as different organizations, for example, Sandvine (2017) and Nielsen (2016).

Kharytonova (2018) examines the objects of intellectual property rights, noting that, as in any activity where there is an element of creativity, in the field of sports there are intellectual property rights to various objects: the right to a name, the right to a brand, a logo, etc.

Recent research has covered specific intellectual property rights, such as image rights in sport. The right to use the name of a celebrity, his/her image, manner, recognizability, reputation today is classified as image rights.

The most complete and detailed study of the rights of an individual to his own image (including in the field of sports) is the monograph of Kulinich (2016) "The right of an individual to his own image: the current state and prospects for development". However, separately the problem of using the image of the athlete and the type of such use is still little studied. The issues of protection of intellectual property rights in the field of sports are not better researched and covered in the scientific literature. Even a cursory review of the achievements in the field of protection of intellectual property rights in the field of sports shows the practical complete absence of relevant research. Therefore, clarifying the concept of sports and intellectual property rights related to it is appropriate and very relevant. 
Evgen Kharytonov, Olena Kharytonova, Maxym Tkalych, Inna Bolokan, Hanna Samilo y Yuliia Tolmachevska

\section{Results and discussion}

It is first necessary to determine which objects of intellectual property rights are inherent in the field of sports, and what is the mechanism of legal regulation of public relations arising in connection with such objects.

Up until the 1960s, running shoes featured flat soles. The University of Oregon's running coach Bill Bowerman took on the task to improve traction and shock absorption in training shoes. He experimented by using his wife's waffle maker to mold rubber spikes on the soles and created a superior running shoe he named the Waffle Trainer. The design revolutionized the sneaker industry. Bowerman and one of his students, Phil Knight, founded Blue Ribbon Sports, which eventually became Nike. Today, Nike has obtained thousands of patents worldwide and now has a patent portfolio that rivals that of many leading companies in the pharmaceutical, automotive, and defense sectors, all traditionally research and development- and technology-intensive industries (Low, 2016).

This example clearly demonstrates the first direction of interaction between intellectual property rights and sports, which is the legal design and protection of rights to inventions, utility models and industrial designs (Design). Relevant public relations belong to the subject of legal regulation of patent law as a sub-institution of intellectual property law.

To fully understand the scope of patenting in sports, it is necessary to provide statistics. So, as can be seen from Table 1, hundreds of thousands of patents are in force in sports, which is commensurate with traditional sectors of the world economy.

Table 1. The number of patents is in force in sports (Global Innovation Policy Centre, 2020).

\begin{tabular}{|l|l|}
\hline Kitesurfing & 14,224 \\
\hline Hockey & 17,668 \\
\hline Polo & 19,793 \\
\hline Soccer & 28,779 \\
\hline Boxing & 32,694 \\
\hline Baseball & 44,468 \\
\hline Tennis & 52,526 \\
\hline Skiing & 110,501 \\
\hline Golf & 112,256 \\
\hline
\end{tabular}


Branding also plays an essential role in creating value, interest, and vitality in sports. It drives consumer loyalty and confidence in the quality and features of sporting goods. It also generates allegiance to sports teams and sportswear styles. Trademarks work differently for goods and for services in the sports sector depending on the product or asset being protected, but the common denominator is the distinctiveness of the mark. Importantly, trademarks provide protection against confusion about the source of a given product.

A trademark is a designation or any combination of designations that are suitable for distinguishing goods (services) produced (provided) by one person from goods (services) produced (provided) by other persons. These can be, for example: words, letters, numbers, pictorial elements, color combinations (Law 435-IV, 2003).

Depending on the form of expression, verbal, pictorial, threedimensional, combined symbols, etc. are distinguished. Verbal symbols can be words, including proper names, combinations of letters, combinations of words, etc. Graphical execution of verbal symbols can be done using a regular or original font. Pictorial symbols include graphic compositions of any shape on the plane: drawings, symbols, etc.

Famous individuals famous athletes, cause increased public attention, encourage the purchase of souvenirs with their image, goods or products that they advertise. Photographs decorate various everyday objects, clothes, utensils, illustrate texts in online publications, print media, advertising products (Subota and Nechiporenko, 2006).

The image of a famous athlete can also be used in the appearance of goods and packaging. Unauthorized imaging is prohibited by law. For example, in Australia, the image on a T-shirt without the permission of the name and image of surfer Terry Fitzgerald, led to a lawsuit for infringement of intellectual property rights of the athlete. The court ruled that the company would refrain from reproducing or granting permission to reproduce all or any part of the surfer's photograph, awarding damages and costs for violating the right to insult. Using a photo of a famous person can be misleading, for example, when it gives the impression that the person in the photo approves of your product, if in fact they do not (Kravets, 2000).

Thus, in particular, in the EU jurisdiction the most famous is the case of Irvine v. Talksport Ltd (England and Wales Court of Appeal, 2003). The radio station bought the rights to the photo with Formula I driver Eddie Irvine, edited the photo a bit (replacing the mobile phone with a radio) and released an advertising poster. The plaintiff believed that the poster created in the audience a false impression of his approval of the defendant's brand. The appeal agreed with the plaintiff and recovered from the radio station damages in the amount of $£ 25,000$. 
Evgen Kharytonov, Olena Kharytonova, Maxym Tkalych, Inna Bolokan, Hanna Samilo y Yuliia Tolmachevska

It should be noted that today the market of well-known names of sports clubs (brands) has actually been formed. The names of sports arenas are for sale. The first classic sale of the name of the sports arena is considered to be the agreement between the New England Patriots (American football) team in 1971: the new stadium in Foxboro was named after the beer brand Schaefer. The advertiser then paid \$150,000 for a 10-year contract. In the early 1990s, the business developed rapidly, spreading to Japan, Australia, and the United Kingdom.

Companies are willing to pay for naming because they are actually buying a place on the city map and attracting not only fans but also a potentially much larger audience, insuring themselves against price changes, booking a place that is attractive for a long time. This phenomenon is called sports naming (Vasiliev and Shamonaev, 2012).

Most often, the colors of the uniforms of national teams repeat the colors of national flags. So professional sport is aimed to unite the nation under the auspices of national symbols, to create a sense of unity with the people. Fans of sports clubs or national teams wear clothes with the colors of the appropriate accessories, decorate themselves with national symbols, paint their faces in the colors of national flags. The combination of colors of the club sports uniform, its specific design, is an important element of visual distinction, which allows an outside observer to immediately distinguish one club from another (Galkin, 2011).

Thus, club colors create a stable associative connection between fans and a football or other sports club.

For example, the information of Prague's Slavia, which was addressed to the club's fans, is indicative in this sense. The club posted information on its official website for fans (who were going to support their team in the return match of the third qualifying round of the Champions League against Dynamo (Kyiv), which would take place on August 14, 2020 in Kyiv), in which they offered fans to avoid possible provocations, to exclude the appearance in the capital of Ukraine in club clothes and with the official symbols of "Slavia", including scarves and flags.

This is due to the similarity of the club colors of Prague with the symbols of the Moscow "Spartak", because the Czech club was afraid of physical attacks on fans given the "sensitivity of Ukrainians to any expression of pro-Russian sentiment” (LB.ua, 2018).

One of the most valuable assets that a sports team has is: "its name, logo and other defining characteristics with which this team is associated in public. In order to be able to protect their rights to these marks, professional sports teams register them accordingly (most often as marks for goods and services) and create a team brand (mark for goods and services with a stable image). This is due to the fact that the economic activity of sports 
organizations is diverse and includes not only sports services but also others, including trade in relevant sports accessories. Thus, clubs have to protect their IP in order to preserve commercial and financial interests. The market price of such goods is determined not so much by their cost as by the reputation of the sports team. As a rule, each professional club has registered marks for goods and services. Brands of football clubs are wellknown all over the world in Ukraine as well" (State Enterprise "Ukrainian Institute of Intellectual Property", 2019).

Logos are varieties of a trademark, its graphic images. There are both team, corporate logos and individual logos that are associated with a famous athlete.

For example, Kawhi, the main player of the NBA playoffs, was suing Nike because of his logo Klaw ("claw") - a large palm in the form of letters $\mathrm{K}$ and $\mathrm{L}$ and the number 2 (game number of the basketball player). The striker is known to have one of the biggest palms in the league. According to Kawhi, Nike has appropriated his "claw". Kawhi insisted, that he came up with and drew the logo while still studying at San Diego State University. Later, after signing a contract with Nike, he allowed the company to use the image with the placement on Jordan Brand products, but according to the lawsuit "never transferred the right to the logo", and the agreement on the logo expired after the expiration of the contract with the company.

In 2018, Leonard did not renew the Jordan Brand contract, giving up \$ 22 million for 4 years, and signed a contract with New Balance. But Nike did not allow the basketball player to use the logo - the company claims that the copyright to Klaw now belongs to them. In the lawsuit, Kawhi asked the court to recognize him as the author of the logo and rule that Nike "cheated" him when registering the copyright for the logo (Sports.ru, 2019).

But most often, companies that produce sports products, try not to use the entire composition of the brand, but only part of it - mainly the label. For example, a major manufacturer of sporting goods and equipment, such as Nike, usually does not advertise the entire brand, but only the so-called Swoosh, i.e., the world-famous graphic element, made in 1971 by American artist Caroline Davids - a tick.

Anthems or musical identifiers of clubs can also be elements of a brand, as the musical environment is one of the forms of recognition of a team. Over time, it is clearly associated with the name of the club or company.

Mottoes and slogans, which are the objects of intellectual property rights, are used by well-known brands, in particular, in the field of sports. It is a means of individualization, which is a short expression (motto, slogan), which in a concise concentrated form expresses the philosophy of the club or company. "Just do it" is a slogan that is easy to remember and in a short poetic embodiment conveys to the consumer the direction of goals and the meaning of the activities of a participant in the sports industry. 
Evgen Kharytonov, Olena Kharytonova, Maxym Tkalych, Inna Bolokan, Hanna Samilo y Yuliia Tolmachevska

538

Intellectual property law in the field of sports: specifics of manifestations and features of legal regulation

The next point of contact between intellectual property rights and sports is the sphere of so-called "Image" rights.

Based on the analysis of image rights, it can be argued that this is a combined concept that includes rights to such objects of civil rights as intangible benefits and results of intellectual activity. The results of intellectual activity include, first of all, photographic works depicting athletes, as well as video recordings or works of visual art on which they are depicted. Intangible benefits within the framework of image rights include the right to privacy, the right to a name and the right to protect the image of a citizen (Vostrikova and Polukhina, 2017).

Image rights can also be defined as follows: Access to the services of the personality for the purpose of filming, television (both live and recorded), broadcasting (both live and recorded), audio recording; motion pictures, video and electronic pictures (including but not limited to the production of computer-generated images; still photographs; personal appearances; product endorsement and advertising in all media; as well as the right to use the personality's name, likeness, autograph, story and accomplishments (including copyright and other intellectual property rights), for promotional or commercial purposes including, but without limitation, the personality's actual or simulated likeness, voice, photograph, performances, personal characteristics and other personal identification (Blackshaw, 2020).

Interesting from the point of view of image rights is the story with one of the photos of Michael Jordan. In 1984, photographer Jacobus Rentmeester took a photo of Michael Jordan (a student at the University of North Carolina). At the time, NIKE was negotiating an advertising contract with Jordan (beginning with the commercialization of athletes' image rights). For $\$ 150$, NIKE bought a license to use the photo in the presentation. A few months later, NIKE hired another photographer for the photo shoot and chose a photo that shows Jordan in the same pose as in the Rentmeester photo, but against the backdrop of a panorama of Chicago. After Rentmeester had found out about this he threatened to sue, and the company bought a two-year license for posters and billboards in the United States. Later, based on the photo of the second photographer, NIKE created a silhouette of "Jumpman", which depicts a player jumping in front of a slam dunk. This silhouette has become a symbol not only of Michael, but also of NIKE, which receives huge profits from the sale of goods with this logo.

Only in 2015 did Rentmeester file a lawsuit alleging copyright infringement. The trial court refused, but the photographer appealed. Rentmeester claimed that he came up with the pose for the basketball player - a classic ballet pose "grand jetés", not typical of basketball players. "Jordan, trying to make a ballet jump, may seem awkward. But if you creatively adapt the composition, the player pulls his left hand forward, 
triumphantly holds the basketball and creates a frame when Jordan seems to fly from the ground to the basketball hoop, creating a powerful and unique effect, "the photographer described the composition. NIKE pointed to a large number of differences in the details of the composition of the photograph. This is the evaluation criterion used by the court: the "ordinary observer" test.

The conceptual similarity of the two photos is that they are taken from the same angle: the viewer looks at the figure of a basketball player against the sky. In other respects, they differ significantly in detail. Each of the photographers made several "creative choices" when choosing the elements of the composition. In March 2018, an appeal was denied to the photographer. The photographer then appealed to the US Supreme Court. Rentmeester noted that the decision of the appeal contradicts the approaches of other courts of appeal in similar decisions: how much protection do individual elements of photography receive? What parts of the works are significant in comparison? Is there enough similarity in one element or in a combination of such elements (Brachmann, 2019).

It should be noted that the concept of "image" rights, which combines elements of the institution of intellectual property law and the institution of personal non-property rights, is also closely related to copyright. Copyright, as a system of legal norms aimed at the legal protection of objects of creative activity, is another manifestation of the institution of intellectual property law in sports.

Kuznetsova (2013) identifies four types of results of creative activity in the field of sports: 1. sports performance [show] or its part as a work of art or as a work of choreography in the sports industry: choreographic composition in figure skating; speed skating sport, which is a complex coordination type; performing with the author's composition in synchronized swimming, etc.; 2. sports-theatrical and sports-circus shows: 2.1 sports-theatrical and sports-circus shows as ceremonies and as part of the opening and / or closing ceremony of major international and national sports events [Olympic Games, Universiades, etc.]; 2.2 ordinary or complex thematic or universal sports-theatrical and sports-circus shows [ice dancing shows, sports and entertainment auto shows and motorcycle shows, etc.]; 3. some original tactical schemes and combinations in some game sports and in some tabletop intellectual sports games; 4 . choreographic miniperformances, which in the strict sense are not sports, but consistently and recognizably preceding each sports performance [show] of a sports team or athlete.

Based on the foregoing, sports performance and its individual elements, sports movements and methods, as well as their compositions, sports events, specific schemes of a sports game, scenarios and broadcasts of a sports event can be identified as specific objects of copyright and related rights in the sports industry. 
Evgen Kharytonov, Olena Kharytonova, Maxym Tkalych, Inna Bolokan, Hanna Samilo y Yuliia Tolmachevska

540

Intellectual property law in the field of sports: specifics of manifestations and features of legal regulation

Indeed, more and more often the field of sports is becoming a theatrical phenomenon. The theatricalization of sports is manifested in the fact that sports events are becoming more and more spectacular, and this, in turn, objectively requires the involvement and active use of theatrical elements. "If before the spectacular sports services were a duel, in which the intrigue of finding a winner remained until the end of the competition, in postmodern culture more and more often a sporting event is theatrical. An example of a sports entertainment show is wrestling, in which all the basic elements of a sports competition are present, except for one: here the development of the event depends on a pre-written scenario, where the result of the match and its climaxes are pre-written. Wrestling combines elements of sports, plays, etc.” (Lukaschuk, 2010).

In addition to the fact that some sports contain elements of a production show as a stand-alone work, music and other works belonging to other persons are often used in the organization of sports competitions. In particular, during important football matches or, for example, boxing matches (the Klitschko brothers), domestic and foreign musicians often perform the national anthem of Ukraine.

With regard to television broadcasts, the issue of legal regulation of the relevant relations does not seem easy.

As for the objects of related rights in the sports industry, in addition to the considered performance by an athlete of a copyrightable sports work, these also include the rights to broadcast a sports event. As a rule, the organizers of physical culture events and sporting events own the rights to their coverage by broadcasting the image and sound of the events by any means and using any technology, as well as by recording the said broadcast and photographing the events; such rights can be used by third parties only on the basis of the permission of the organizers of physical culture events and (or) sports events or agreements in writing on the acquisition of these rights by third parties from the organizers of such events. In addition to national legislation, many relations regarding the coverage of sports events are governed by the regulations of sports organizations, including the rules of the Olympic Charter, FIFA and UEFA regulations, as well as other documents of the international sports movement, which, as a rule, enshrine the exclusive rights of such organizations to broadcast.

At the same time, as a protected object of intellectual property, a broadcesting on the air or by cable of radio or television transmissions that belong to the broadcasting or cable broadcasting organization is considered. That is, legal protection extends to the process by which programs are broadcast on air or by cable, which, as an object of law, arises from the moment the broadcast begins. Sports broadcasts can "be, for example, reports from the scene, broadcasting competitions, thematic discussions," films "about famous athletes or events in the world of sports" (Buzova, 2019). 
Some of these categories of broadcasts, if there is a creative contribution to their creation, may be recognized as audiovisual works, which are also subject to independent copyright protection. For example, such as films about sports, talk shows and interviews with athletes, which are created by broadcasting organizations on purpose, have a script or plot scheme, suggest the selection of a studio or location for shooting, possibly with the use of scenery and musical accompaniment, the use of makeup and costumes, an invitation special guests and (or) spectators, and sometimes a production director, as well as fixation on a material or digital medium. Discussion is the issue of the legal status of broadcasting sports events and news reports from the place of sports events. Undoubtedly, their broadcasting is subject to protection by related law (Dorofeeva, 2020). However, per se, news reports that are purely informational in nature are not subject to copyright protection. In fact, broadcasts of sports events are also material broadcast from a football field or other sporting event that is not subject to copyright protection.

An absolutely innovative field of modern sport, which uses a unique model of legal regulation of intellectual property relations in sports, is e-sports. This sport is already recognized by many countries around the world and may soon be recognized as an Olympic sport. WIPO has described the complexity of video game Intellectual Property rights by stating that video games are complex works of authorship - containning multiple art forms, such as music, scripts, plots, video, paintings, and characters that involve human interaction while executing the game with a computer program on a specific hardware. Therefore, video games are not created as a single, simple works, but are an amalgamation of individual elements that can each individually be copyrighted (Ramos et al., 2013).

Also, a unique feature of e-sports is that the exclusive rights to e-sports games belong to their developers, which allows them, unlike traditional sports, to control all processes related to the organization and conduct of e-sports competitions.

\section{Conclusions}

As a result of the study, the authors of the article came to two key conclusions:

1. A modern system of sports cannot exist without a developed system of intellectual property rights.

Sport has long been more than just one way to stay fit. Instead, sport has long been an entertainment industry that has become an important sector of the world economy. Accordingly, like any other branch of the 
Evgen Kharytonov, Olena Kharytonova, Maxym Tkalych, Inna Bolokan, Hanna Samilo y Yuliia Tolmacheuska

sports economy, it requires a number of legal instruments to protect the intellectual property rights of products produced by the industry and are the objects of intellectual property rights of athletes and / or other participants in a wide range of sports relations. The focus of modern sports on the consumer, the commercialization of relations in the field of sports would be limited without innovation, the determinants of which are television and the Internet. It is innovative technologies that allow millions of spectators to watch sporting events that take place anywhere on the planet with direct visitors. And if until recently for exclusive broadcasts had to pay a lot of money, because this opportunity was provided only by television as a monopolist, today access to sports broadcasts has become much easier, and they can be watched even on a smartphone through any streaming service. In addition, a completely innovative field of sport is e-sports, as a unique direction of modern sports.

2. World sport has many points of contact with intellectual property rights, which is manifested in the relevant relations through a number of its sub-institutions.

Traditional intellectual property rights in sports have been trademarks and inventions. At the same time, today they were joined by a number of other objects, including utility models, industrial designs, objects of copyright and related rights, as well as the latest objects of "image" rights, combining elements of the institute of intellectual property law. property and the institution of personal non-property rights.

Thus, the emergence of new intellectual property in sports, the search for new innovative tools to bring the sporting product to the consumer determine the relevance of further research in the context of interaction of intellectual property and sport, developing a global model of legal and quasi-legal regulation of relevant relations. for the purpose of sustainable development of sports and ensuring the protection of the rights and legitimate interests of all participants in relations in the field of sports.

\section{Bibliographical References}

ANDERSON, Mathew. 2017. "Sports Broadcast Copyright in China: The Stranglehold of Originality” In: Harris Bricken. Available online. https:// www.chinalawblog.com/2017/06/sports-broadcast-copyright-in-china. html. Date of consultation: 12/02/2021.

ANDROSCHUK, Genadii. 2008. "The most powerful brands in the world: status and trends" In: Intellectual Property. Vol. 12, pp. 21-25. 
ANDROSCHUK, Genadii. 2011a. "Rating of national brands" In: Intellectual Property. Vol. 9, pp. 29-44.

ANDROSCHUK, Genadii. 2011b. "Weakness of well-known and famous signs (weakening of the recognizability or advertising value of the mark for goods and services): part 1” In: Intellectual property. Vol. 12, pp. 25-31.

BLACKSHAW, Ian. 2020. Understanding Sports Image Rights. In: WIPO. Available online. In: https://www.wipo.int/ip-outreach/en/ipday/2019/ understanding_sports_image_rights.html. Date of consultation: $12 / 02 / 2021$.

BOLOKAN, Inna; SAMOYLENKO, Georgiy; TKALYCH, Maxym; PANCHENKO, Bogdan; DMYTRIV, Volodymyr. 2021. "Sanctions in Sport: The Relationship Between Legal and Local Regulation” In: Retos. Vol. 42, pp. 662-672.

BRACHMANN, Steve. 2019. Supreme Court Asked to Decide Copyrightable Elements of Iconic Michael Jordan Photograph. In: IPWatchdog. Available online. https://www.ipwatchdog.com/2019/01/o7/supremecourt-rentmeester-michael-jordan-photograph/id=104650/. Date of consultation: 12/02/2020.

BUZOVA, Nataliia. 2019. "Sports programs: topical issues of legal protection and protection of rights to them" In: Law. Journal of the Higher School of Economics. Vol. 1, pp. 195-213. Available online. In: https://cyberleninka. $\mathrm{ru} /$ article/n/sportivnye-peredachi-aktualnye-voprosy-pravovoyohrany-i-zaschity-prav-na-nih. Date of consultation: 26/03/2020.

DOROFEEVA, Anastasiia. 2020. "Specific objects of copyright and related rights in the sports industry" In: New legal bulletin. Vol. 6, No. 20, pp. 50-56. Available online. In: https://moluch.ru/th/9/archive/171/5236/. Date of consultation: 26/03/2020.

ENGLAND AND WALES. 2003. Court of appeal: Decision 423/2003 of April 12., Irvine v. Talksport Ltd. Available online. In: https://www.casemine. com/judgement/uk/5b46f1ec2c94e0775e7ee2e2. Date of consultation: 12/02/2021.

GALKIN, Vadym. 2011. Trademarks and naming in the sports business. Available online. In: http://vadim-galkin.ru/sport-2/sport-business/ trademarks-and-naming-in-the-sports-business/. Date of consultation: 12/02/2021.

GLOBAL INNOVATION POLICY CENTRE. 2020. Leveraging intellectual property in the global sports economy. Available online. In: https:// www.theglobalipcenter.com/wp-content/uploads/2018/o6/o23441 GIPC_Sports_Econ_Insides_03.pdf. Date of consultation: 12/02/2021. 
Evgen Kharytonov, Olena Kharytonova, Maxym Tkalych, Inna Bolokan, Hanna Samilo y Yuliia Tolmachevska

KHARYTONOV, Evgen; KHARYTONOVA, Olena; KOSTRUBA, Anatolii; TKALYCH, Maxym; \& TOLMACHEVSKA, Yuliia. 2021. "To the Peculiarities of Legal and Non-Legal Regulation of Social Relations in the Field of Sport” In: Retos. Vol. 41, pp. 131-137. Available online. In: https://recyt.fecyt.es/index.php/retos/article/view/84178/62960. Date of consultation: 12/02/2021.

KHARYTONOVA, Olena. 2018. Sports Law. In: Phoenix. Odesa, Ukraine.

KODYNETS, Anatoliy. 2006. "Means of individualization of participants of civil turnover, goods and services in civil law of Ukraine". Doctoral thesis. Taras Shevchenko National University of Kyiv, Kyiv. Available online. in: http://www.lib.ua-ru.net/diss/cont/129766.html. Date of consultation: 05/06/2020.

KOLOMOIETS, Tetianal; TKALYCH, Maxym; MELNYK, Petro; PANCHENKO, Bogdan; TOLMACHEVSKA, Yuliia. 2021. "Combating Corruption in Sport: Legal Aspect” In: Retos. Vol. 41, pp. 746-755.

KRAVETS, Leonid. 2000. "The Protection and Use of Names and Images in British Trade: A Digest. Patent case" In: Digest of Russian and foreign press. Vol. 7, pp. 14-17.

KULINICH, Olha. 2016. The right of an individual to his own image: the current state and prospects of development: monograph. In: Legal Literature. Odessa, Ukraine.

KUZNETSOVA, Anna. 2013. Civil-legal protection of the results of creative activity in the field of sports in Russia and foreign countries. Doctoral thesis. Peoples' Friendship University of Russia, Moscow. Available online. In: https://www.dissercat.com/content/grazhdanskopravovaya-okhrana-rezultatov-tvorcheskoi-deyatelnosti-v-sfere-sportav-rossii-i-/read. Date of consultation: 26/o3/2020.

LB.UA. 2018. Czech "Slavia" recommended fans not to walk around Kyiv in club symbols. The colors of the Prague club are similar to the colors of the Moscow "Spartak". Available online. In: https://ukr.lb.ua/ sport/2018/08/13/404981_cheska_slaviya_rekomenduvala_fanam. html. Date of consultation: 26/03/2020.

LOW, Elaine. 2016. "Why Nike has more Patents than Lockheed, Ford and Pfizer" In: Investor's Business Daily. Available online. In: https://www. investors.com/news/a-nike-apple-watch-an-under-armour-baseballline-patents-hold-secrets/. Date of consultation: 26/03/2020.

LUKASCHUK, Vitalii. 2010. "Sport as a kind of show business" In: Bulletin of Kharkiv National University Karazina. Vol. 889, pp. 
129-132. Available online. In: http://ekhnuir.univer.kharkov.ua/ bitstream/123456789/4987/2/Lukawuk.pdf. Date of consultation: 26/03/2020.

NIELSEN. 2016. Catch it Live: Sports Viewing Scores a Programming Goal. Available online. In: https://www.nielsen.com/us/en/insights/ article/2016/catch-it-live-sports-viewing-scores-a-programming-goal/. Date of consultation: 26/03/2020.

PIHURETS, Olena. 2005. Protection of the right to a trademark (civil law aspect) Doctoral thesis. National University of Internal Affairs. Kharkiv, Ukraine.

RAMOS, Andy; LÓPEZ, Laura; RODRÍGUEZ, Anxo; MENG, Tim; ABRAMS, Stan. 2013. "The Legal Status of Video Games" In: WIPO. Available online. https://www.wipo.int/edocs/pubdocs/en/wipo_report_cr_ vg.pdf. Date of consultation: 26/03/2020.

RASSOMAKHINA, Olha. 2008. Legal regulation of the use of trademarks in economic turnover. Ukraine. Doctoral thesis. Kyiv National Economic University named after Vadym Hetman, Kyiv, Ukraine.

ROMANADZE, Luisa. 2008. Protection of trademark rights in private international law. Doctoral thesis. National University "Odesa Law Academy”, Odesa. Available online. In: http://hdl.handle. net/11300/803. Date of consultation: 26/03/2020.

SADOVNYK, Alla. 2015. On himself - an embroidered shirt, for sale - "false" adidas. Evening Rivne. Available online. In: https://rivnepost.rv.ua/ news/na-sebe-vishivanku-naprodazh-liviyadidas. Date of consultation: 26/03/2020.

SANDVINE. 2017. 2017 Global Internet Phenomena Spotlight: Subscription Television Piracy. Available online. In: https://www.sandvine.com/ hubfs/downloads/archive/2017-global-internet-phenomena-spotlightsubscription-television-piracy.pdf. Date of consultation: 26/03/2020.

SHARMA, Seemantani. 2017. "Copyright Protection over Sports Broadcasts: A Global Perspective” In: Abu Sports Group. Available online. In: http://www.abu.org.my/images/articles/Legal/articles/Copyright\%20 Protection\%20Over\%20Sports\%20Broadcasts.pdf. Date of consultation: 26/03/2020

SPORTS.RU. 2019. Kawhi is suing Nike. His personal logo was taken away from him. Available online. In: https://www.sports.ru/tribuna/blogs/ bankshot/2471881.html. Date of consultation: 12/22/2020. 
Evgen Kharytonov, Olena Kharytonova, Maxym Tkalych, Inna Bolokan, Hanna Samilo y Yuliia Tolmachevska

STATE ENTERPRISE "UKRAINIAN INSTITUTE OF INTELLECTUAL PROPERTY". 2019. Ukrainian sports and intellectual property. To the International Day of IP. Available online. In: https://ukrpatent.org/ uk/news/main/ip-sport-ukraine-2019-18042019. Date of consultation: 12/22/2020.

SUBOTA, Nataliia; NECHIPORENKO, Andrii. 2006. "Copyright in a photographic work: problematic aspects of judicial protection" In: Intellectual Property, Vol. 3, pp. 11-14.

TKALYCH, Maxym; DAVYDOVA, Iryna; TOLMACHEVSKA, Yuliia. 2020. "Current State and Prospects of Development of the Sports System of Ukraine: Legal Aspects (Estado actual y perspectivas de desarrollo del sistema deportivo de Ucrania: aspectos legales)" In: Retos, Vol. 38, pp. 385-389, Available online. https://recyt.fecyt.es/index.php/retos/ article/view/76997. Date of consultation: 12/22/2020.

UKRAINE. 2003. Law 435-IV/2003, of January 16, Civil Code of Ukraine. Available online. In: https://zakon.rada.gov.ua/laws/show/43515\#Text. Consultation date: 11/02/2021.

VASILIEV, Ivan; SHAMONAEV, Oleg. 2012. "How the business of selling the names of sports arenas works" In: Forbs. Available online. In: https:// www.forbes.ru/sobytiya-opinion/sport/95043-kak-ustroen-biznes-poprodazhe-nazvanii-sportivnyh-aren. Consultation date: 11/02/2021.

VOSTRIKOVA, Elena; POLUKHINA, Ruzanna. 2017. "Image rights of athletes in Russia as an institution of private law" In: Center Bereg. Available online. https://center-bereg.ru/b509.html. Consultation date: 11/02/2021

WIPO. 2020. World Intellectual Property Day 2019 - Reach for Gold: IP and Sports. Available online. In: https://www.wipo.int/ip-outreach/en/ ipday/2019/dg_message.html. Date of consultation: 14/11/2020. 

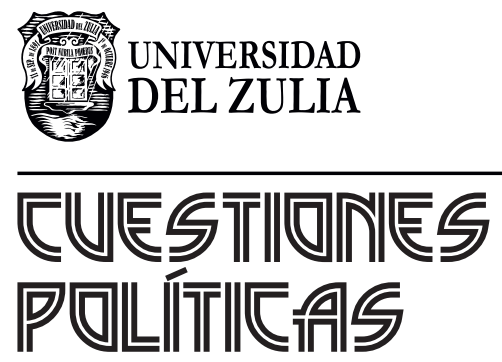

Vol.39 No 69

Esta revista fue editada en formato digital y publicada en julio de 2021, por el Fondo Editorial Serbiluz, Universidad del Zulia. Maracaibo-Venezuela 